\title{
Isolation, identification and Partial Purification of Lectin from Typhonium trilobatum.
}

\author{
Mrityunjoy Biswas ${ }^{1}$, Niranjan Kumar Sana ${ }^{2}$ \\ Dept. of Biochemistry and Molecular Biology, University of Rajshahi, Bangladesh.
}

\begin{abstract}
In this investigation we included isolation, identification and partial purification and some characterizations of purified Lectin from Typhonium trilobatum. During the summer seasons, the rhizome of Typhonium trilobatum was collected from different sites of Rajshahi in Bangladesh and various steps were followed to isolate crude protein extract.

For identification of protein, we used Hemaglutination activity assay and its agglutinated human $\left(o^{+v e)}\right.$ blood cells. Lectin was purified by using DEAE-Cellulose column chromatography and UV Spectrophotometric method. During purity checking and molecular weight determination we used Gel Electrophoresis method and moved three bands. The molecular weight was calculated from the standard curve of reference proteins which was constructed by plotting molecular weight against relative mobility of the reference proteins on gel after electrophoresis and the molecular weight of the partial purified Lectin as determined by SDS-PAGE. It assumed that there were three Lectins present and estimated to be $19 \pm 1 \mathrm{kDa}, 40 \pm 1 \mathrm{kDa}$ and $90 \pm 1 \mathrm{kDa}$ of their molecular weights. The minimum concentration of Hemaglutination activity assay was $15.4 \mu \mathrm{g} / \mathrm{ml}$. These Lectins showed slight toxicity towards brine shirmp nauplii, the $L C_{50}$ value was 9.90648. These Lectins also showed slight antibacterial activity against Escherichia coli (123 $\mu \mathrm{g} /$ disc and $184.8 \mu \mathrm{g} /$ disc).

We can develop techniques and knowledge of protein chemistry, molecular biology including genetic engineering, and structural biology including analysis for the structure-activity relationship and clarification for the mechanism of enzymatic reaction to promote the research.
\end{abstract}

Keywords: Characterizations, Clarification, Electrophoresis, Hemaglutination, Toxicity.

\section{Introduction:}

Bangladesh is a developing country. It has immense natural resources; its flora and fauna are so plenty and rich that very few countries can vie with it in this regard. It abounds with great numbers of plants diverse varieties. Its plant resources have great medicinal as well as nutritive value. Typhonium trilobatum is one them. Typhonium trilobatum is a plant and belongs to the family Araceae. The genus Typhonium contains about 25 species, distributed over the tropical regions of the world. It occurs in India, Burma, Malaya, Siam, Ceylon, China, Malaysia and North Australia. ${ }^{[1]}$ Typhonium trilobatum is one of the common aroids of Bengal. It is a perennial herb and easily recognized by its three-loabed hastate leaves, which appear to rise directly from the ground. It has been reported from various parts of Bangladesh such as Khulna, Rajshahi, Jessore, Magura, Kustia, Natore, Pabna, Sirajgonj etc. It is a summer vegetable in Bangladesh. The plant grows every place around the house, fall land and jungles. They grow in waste places and profusely flower from the later part of April to the end of October; rarely do they form a pure community. Now-a-days in Bangladesh it is commercial cultivated in Lalpur, Natore, Abdulpur, Jessore etc. ${ }^{[2]}$

If its untapped resources are properly utilized, and if its plants are scientifically processed and properly marketed, its economy will be viable one, and it may soon be aligned with the developed countries of the world. It may soon become poverty free, academically progressing and politically leading country. In our country, so far I know, no detailed study has been conducted to purify the protein from Typhonium trilobatum.

Lectins, found in plants, bacteria, fungi, invertebrates, and vertebrates, are proteins that specifically bind to carbohydrate. ${ }^{[3]}$ The recognition of carbohydrate structure displayed on cell surfaces has been well studied to investigate cell-cell interactions, since a Lectin has two or more carbohydrate-binding sites to facilitate the cell adhesion. Based on such unique binding properties, Lectins play a diversely significant role in biological functions in animals. For example, 1) the multiple binding of Lectins to blood cells is well known to cause the agglutination that is designated as hemagglutination, 2) the Lectin that recognize galactose residues found on the surface of mammalian liver cells are believed to act as cell-surface receptors that are responsible for the removal of certain glycoprotein from a circulatory system, and 3) Lectin that recognizes mannose-6-phosphate has enzymatically hydrolytic activity, acting as a receptor for delivery to the lysosomes. Recently, specific cell agglutination has been reported to inactivate certain types of tumor cell. In addition, Lectins that recognize carbohydrates found in pathogens act as a part of immune system or antibiotics. Keeping all these in mind, in this study I make an attempt to isolation, identification and partial purification of Lectin from Typhonium trilobatum. 


\subsection{Collection of Sample}

\section{Method and Materials:}

During the summer seasons, Typhonium trilobatum was collected from Rajshahi University campus. After collection, it was cleaned, and stored at room temperature.

\subsection{Preparation of crude extract}

$50 \mathrm{~g}$ rhizome of Typhonium trilobatum was cut into small pieces and then $100 \mathrm{ml}$ of pure water was added and the sample was homogenized by a homogenizer. The homogenate was occasionally stirring and then filtered through a muslin cloth. The filtrate was collected and clarified further by centrifugation at $8000 \mathrm{rpm}$ at $4^{\circ} \mathrm{C}$ for 15 minutes. The clear supernatant was collected and dialyzed against cold distilled water for $2 \mathrm{~h}$. After centrifugation, the clear supernatant was used as crude protein extract and also preserved in the deep freeze for experimental purposes.

\subsection{Purification of Lectin}

\subsubsection{DEAE-CELLULOSE Column Chromatography:}

2.3.1.1 Activation of DEAE-cellulose powder: The DEAE-cellulose powder was suspended in $0.2 \mathrm{M} \mathrm{NaOH}$ in a beaker and left it to swell for $3 \mathrm{hr}$. During swelling it was stirred gently at short intervals to prevent formation of lumps. Then it was transferred to a filtering funnel and washed with distilled water for several times until its $\mathrm{pH}$ reached to 4.0. The gel suspension was then transferred to another beaker containing $0.2 \mathrm{M} \mathrm{NaOH}$ and left for another $3 \mathrm{hr}$. It was again washed with distilled water for several times until its pH reached to 7.0.

2.3.1.2Packing in the column: The activated DEAE-cellulose suspension was taken in a filtering flask and deaerated by vacuum pump. A column of $(1.5 \times 12 \mathrm{~cm})$ length was packed with the activated column material. Precaution was taken to avoid trapping of air bubbles during packing.

2.3.1.3Equilibration of the column: After packing, the column was equilibrated with $10 \mathrm{mM}$ Tris- $\mathrm{HCl}$ buffer, $\mathrm{pH} 8.2$

2.3.1.4 Preparation and application of sample: The dialyzed sample was loaded on to DEAE column at $4^{\circ} \mathrm{C}$. The elution was performed by increase of sodium chloride salt concentration from 0 to $0.5 \mathrm{M}$ in the same buffer. An automatic fraction (SF-160) collector was used to collect the eluent. Absorbance of each fraction was measured at $280 \mathrm{~nm}$ and the protein concentration was determined by the Lowry method (Lowry et al. 1951)

\subsection{Test of Purity}

2.4.1 SODIUM DOECYL SULFATE POLYACRYLAMIDE SLAB GEL ELECTROPHORESIS (SDS-PAGE) METHOD: The protein pattern of the selected fraction was determined 10\% SDS-PAGE according to the method of Laemmli (1970) ${ }^{[4]}$ as modified by smith (1995) ${ }^{[5]}$.

\subsection{DETERMINATION OF PROTEIN CONCENTRATION}

2.5.1The protein concentration was determined by the Method of Lowry et al., 1951 ${ }^{[6]}$

2.6 HEMAGLUTINATION ACTIVITY TEST

\subsubsection{Preparation of 2\% Erythrocytes}

Blood group specificity was tested using two different types of human blood groups collected from two donors and blood of chicken was collected from a slaughter house. All the blood samples were collected in $1 \% \mathrm{NaCl}$ and centrifuged at 4,000 rpm for $10 \mathrm{~min}$. The erythrocyte pellet was washed thrice with and resuspended in the same saline to make a $2 \%$ RBC suspension.

\subsubsection{HEMAGLUTINATION ASSAY}

The hemaglutination assay was performed in 96-well microtiter U-bottomed plates in a final volume of $100 \mu \mathrm{l}$ containing $50 \mu \mathrm{l}$ of protein solution serially diluted with an equal amount of hemaglutination buffer (20 $\mathrm{mM}$ Tris- $\mathrm{HCl}$ buffer, $\mathrm{pH} 7.8$ containing $0.9 \% \mathrm{NaCl}$ and $10 \mathrm{mM} \mathrm{CaCl} 2$ ) and $50 \mu \mathrm{l}$ of $2 \%$ suspension of $\mathrm{O}^{+(\mathrm{ve})}$ erythrocytes previously washed with $0.15 \mathrm{M} \mathrm{NaCl}$. After gently shaking, the plate was kept at room temperature for $30 \mathrm{~min}$. The visual agglutination titer of the maximum dilution giving positive agglutination was recorded.

\subsection{DETERMINATION OF CYTOTOXICITY OF THE PURIFIED PROTEIN BY BRINE- SHIRMP BIOASSAY:}

2.7.1 This bioassay can be used as a convenient monitor for screening and fractionation in the discovery and monitoring of bioactive natural products (Mc Laughlin et al., 1990; Perssone et al., 1980; Meyer et al., 1982) ${ }^{[7]}$.

2.7.1.1 Preparation of simulated seawater 
$38 \mathrm{~g}$ of sea-salt (non ionized $\mathrm{NaCl}$ ) was weighed accurately, dissolved in one liter of sterilized distilled water and then filtered off to get clear solution. The $\mathrm{pH}$ of the seawater was maintained between 8 and 9 by using $\mathrm{NaHCO}_{3}$ solution.

\subsubsection{Hatching of brine shrimp}

Artemia salina leach (brine shrimp eggs) collected from the pet shop was used as the test organism. Simulated sea water was taken in the small tank and the shrimp eggs $(1.5 \mathrm{~g} / \mathrm{l})$ were added to one side of the tank and this side was covered. The shrimps were allowed for one days to hatch and immature as nauplii (larvae.).Constant oxygen supply was carried out and constant temperature (around $37^{\circ} \mathrm{C}$ ) was maintained during the hatching time. The hatched shrimps were attracted to the lamp on the other side of the divided tank through dam. These nauplii were taken for this bioassay.

\subsubsection{Preparation of sample}

The test sample contained $6.16 \mathrm{mg} / \mathrm{ml}$ Lectin. This solution was used as a stock solution.

\subsubsection{Application of the test sample and brine shrimp nauplii to the vials}

Twelve clean vials were taken for the sample in four concentrations (Three vials for each concentration) and another three vials were also taken for control. Then the concentration of every three vials was 20, 50, 100 and $200 \mu \mathrm{g} / \mathrm{ml}$ respectively Lectins solution containing sample were added to the each three vials gradually and finally marked up to $3 \mathrm{ml}$ by seawater. With the help of a Pasteur pipette 20 living shrimps were taken to each sample vials and control vial respectively.

\subsubsection{Counting of nauplii}

After 24-hour of incubation, the vials were observed using a magnifying glass and the number of survivors in each vial were counted and noted. From this, the nauplii were counted averagely of each three vials, which contained same conc. of sample the percent (\%) mortality was calculated for each dilution. The concentrationmortality data were analyzed by using Probit analysis (Finney et al., 1971) ${ }^{[8]}$.

\subsection{ANTIBACTERIAL ACTIVITY STUDY}

\subsubsection{Principle of agar dises diffusion method}

In the discs diffusion assay, the surface of a nutrient agar medium contained in a petri dish was uniformly inoculated with the test bacterial culture. Test sample solution was applied on filter paper disc with the help of a micropipette and dried in room temperature. The filter paper discs were then placed on each of the Petri dishes previously inoculated.

\subsubsection{Procedure to determine antibacterial activity}

Antibacterial activity was determined keeping the Petri-dishes in room temperature 6-12 h. This method was developed by Bondi and standardized by Bauer et al in 1966 for susceptibility test.

\section{Result and Discussion}

\subsection{Purification of Typhonium trilobatum lectin by DEAE-CELLULOSE Column chromatography}

The supernatant of protein solution after centrifugation was dialyzed against distilled water for $12 \mathrm{~h}$. After removal of the insoluble material, the clear supernatant was applied to the DEAE-cellulose column previously equilibrated with $10 \mathrm{mM}$ Tris- $\mathrm{HCl}$ buffer, $\mathrm{pH} 8.2$ of the same $\mathrm{pH}$ at $4^{\circ} \mathrm{C}$. The unbound protein fraction was eluted with the same buffer and the bound fraction was eluted with the linear gradient of $\mathrm{NaCl}(0-0.5 \mathrm{M})$ as shown in Fig-3.1 unbound (not shown) and bound fractions-2, 3 and 4 did not show any Lectin activity. Only fraction-1 gave Lectin activity and each tube was subjected for SDS-PAGE for purity check. Only the tubes indicated by solid bar gave three bands as shown in Fig-3.2 and was collected as partial pure Lectin for characterization.

\subsection{DETERMINATION OF MOLECULAR WEIGHT by SDS-PAGE Method}

The molecular weights of purified proteins were determined by SDS-polyacrylamide gel electrophoresis using Bovine Serum Albumin (BSA) (MW. 67 kDa), Ovalbumin (MW. 45 kDa), and Carbonic anhydrase (MW. $29 \mathrm{kDa}$ ), Trypsin Inhibitors (MW. $20 \mathrm{kDa}$ ) as reference proteins. The molecular weight was calculated from the standard curve of reference proteins which was constructed by plotting molecular weight against relative mobility of the reference proteins on gel after electrophoresis and the molecular weight of the partial purified lectin as determined by SDS-PAGE. It assumed that there were three lectins presented and estimated to be $19 \pm 1 \mathrm{kDa}, 40 \pm 1 \mathrm{kDa}$ and $90 \pm 1 \mathrm{kDa}$ of their molecular weights. 
Isolation, identification and Partial Purification of Lectin from Typhonium trilobatum.

\subsection{HEMAGGLUTINATION ASSAY}

The minimum agglutinating activity of the purified Lectin was found to be $15.4 \mu \mathrm{g} / \mathrm{ml}$ for $\mathrm{O}^{+}$(ve) Fig.3.3. Showed minimum partial purified Lectin concentration required for a visible agglutination.

\subsection{RESULT OF BRINE-SHIRMP LETHALITY BIOASSAY}

In brine-shrimp lethality bioassay, the Lectin showed positive results indicating that the Lectin is cytotoxic in nature (Table-3.1) The mortality rate of brine-shrimp nauplii was found to be increasing with the increase of concentration of the Lectin and a plot of concentration vs. percentage mortality gave a linear correlation (Fig 4.6). By using Probit analysis, $\mathrm{LC}_{50}$ was determined by exploration and the $\mathrm{LC}_{50}$ values are $94.9064 \mu \mathrm{g} / \mathrm{ml}$.

\subsection{RESULTS OF ANTIBACTERIAL ACTIVITY}

The antibacterial activity of partial pure lectin solution was determined at doses $123.2 \mu \mathrm{g} / \mathrm{disc}$ and 184.8 $\mu \mathrm{g} / \mathrm{disc}$ that did not give zone against Bacillus cereus, Staphylococcus aureus, Bacillus subtilis, Bacillus megaterium, Shigella sonnei, Shigella shigae, Shigella dysenteriae, Salmonella typhi that gave a small zone against. Escherichia coli. Fig.-3.6: Effect of partially purified Lectin on Escherichia coli.

\section{Figures And Tables}
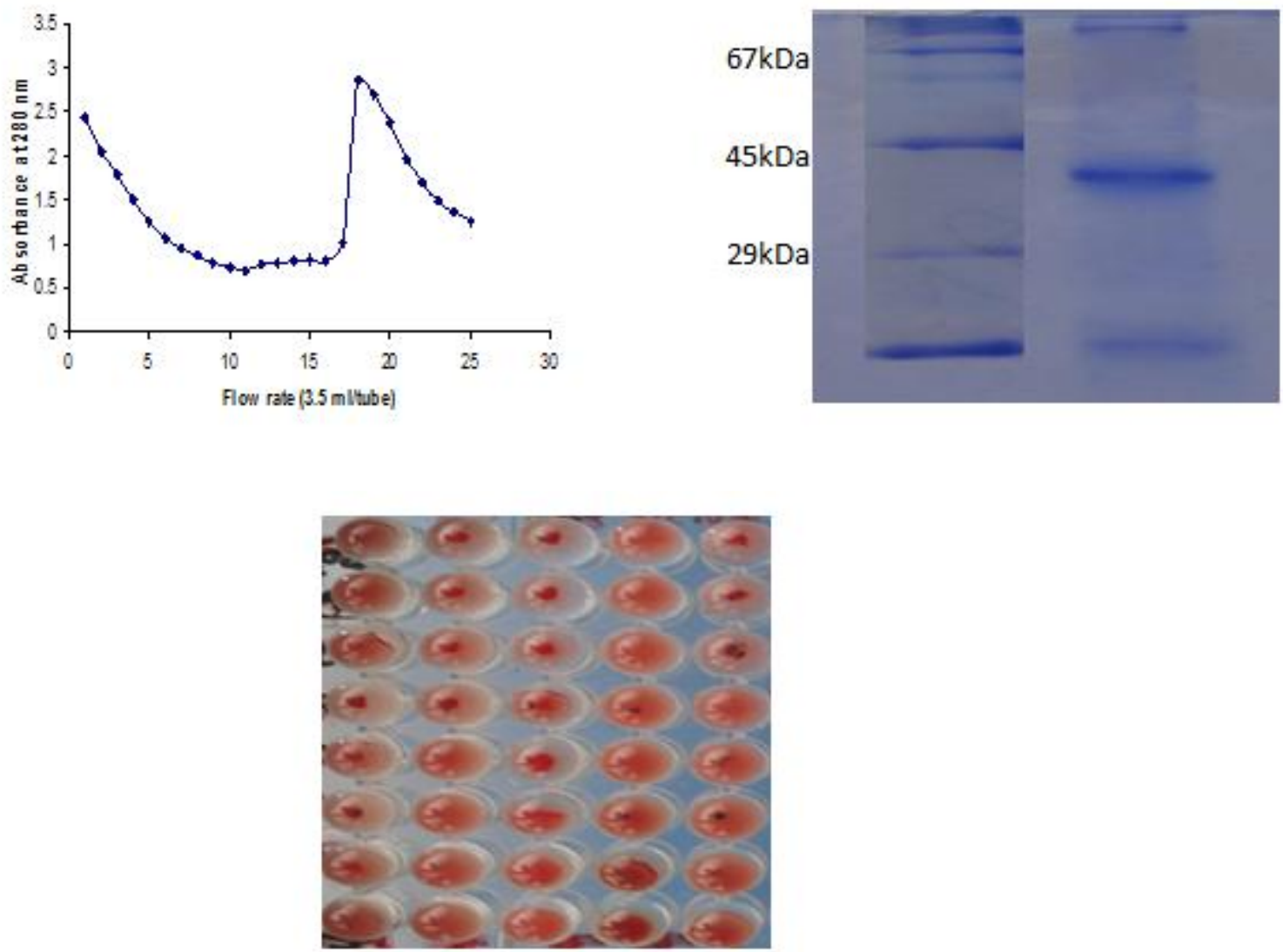

Fig.-3.3:Minimum partial purified Lectin concentration required for a visible agglutination.

$20 \mathrm{kDa}$

Fig 3.1: Ion exchange chromatography of Typhonium trilobatum extract on DEAE-Cellulose chromatography

\section{Lane-1 Lane-2}

Fig-3.2: purity check and Molecular weight determination of Lectin by SDS-PAGE. and Lane-1 marker protein Lane-2 partial pure Lectin 


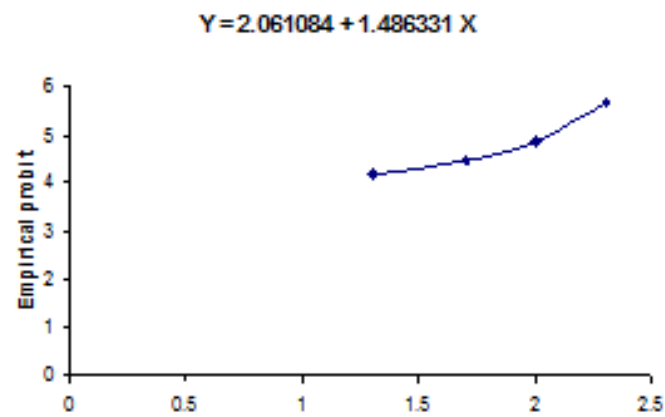

Fig.3.4: Regression line of log dose of pure Lectin solutions against brine -shrimp nauplii after $24 \mathrm{~h}$ of exposure

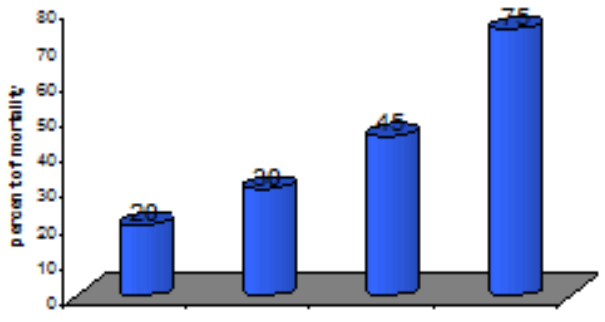

Fig.-3.5: Percent mortality of brine shrimp treated with pure Lectin solutions after $24 \mathrm{~h}$ exposure.

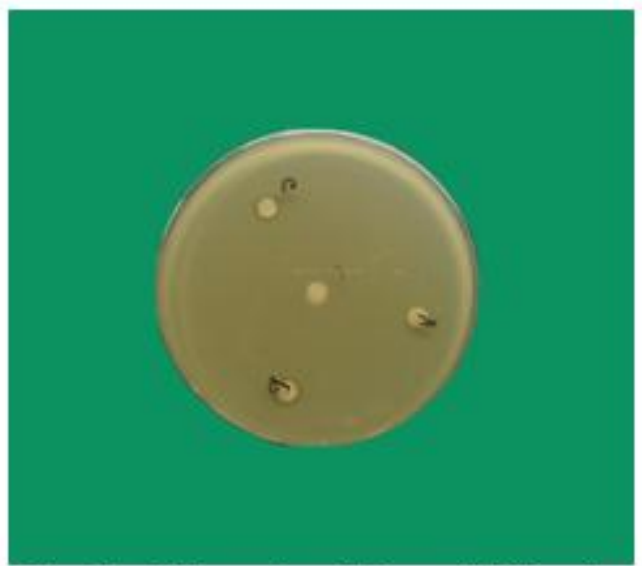

$$
\begin{aligned}
& \mathrm{SC}=\text { Solvent control } \\
& \mathrm{A}=61.6 \mu \mathrm{g} / \text { disc } \\
& \mathrm{B}=123 \mu \mathrm{g} / \text { disc } \\
& \mathrm{C}=184.8 \mu \mathrm{g} / \text { disc }
\end{aligned}
$$

Fig.-3.6: Effect of partially purified Lectin on Escherichia coli.

Table-3.1: Probit mortality of brine shrimp nauplii by partial pure of lectin solution after $24 \mathrm{~h}$ of exposure. ESTIMATE

$\mathrm{Y}=2.061084+1.486331 \mathrm{X}$

\begin{tabular}{|c|c|c|c|c|c|c|c|c|c|c|}
\hline Dose & Log dose & Number & Kill & $\%$ Kill & Corr \% & Emp probit & $\begin{array}{c}\text { Expt } \\
\text { probit }\end{array}$ & $\begin{array}{c}\text { Wrk } \\
\text { probit }\end{array}$ & Weight & Final probit \\
\hline 20 & 1.301 & 20 & 4 & 20.000 & 20 & 4.16 & 4.027 & 4.160 & 8.78 & 3.999 \\
\hline 50 & 1.699 & 20 & 6 & 30.000 & 30 & 4.48 & 4.160 & 4.470 & 12.02 & 4.586 \\
\hline 100 & 2.000 & 20 & 9 & 45.000 & 45 & 4.87 & 5.051 & 4.875 & 12.74 & 5.034 \\
\hline 200 & 2.301 & 20 & 15 & 75.000 & 75 & 5.67 & 5.492 & 5.645 & 12.02 & 5.481 \\
\hline
\end{tabular}

\section{CHI-SQUARED IS 1.045886 WITH 2 DEGREES OF FREEDOM}

NO SIG HETEROGENEITY

LOG LD-50 IS 1.977296

LD-50 IS 94.90648

95\% CONF LIMITS ARE 59.192971 TO 152.1674

\section{Conclusion}

In order to obtain the experimental evidence that there is the substance having the above biological activities in the plant, especially whether such kind of Lectins exist in the plants or not, we performed three bioassays as follows. First, we found that a soluble extract from the rhizome of Typhonium trilobatum has the hemaglutination activity against human (o+ve) blood cell. This result indicates that the rhizome contains Lectin. Second, in vitro study of the extract shows antibacterial activity against E.coli. This results support that medicinal uses such as piles, skin disease, or diarrhea would be appropriate. Finally, Brine-Shirmp bioassay shows the cytotoxic activity of the extract. This result indicates it may have anti-neoplastic activity.

In order to keep on studying such research, more sophisticated facilities are needed. From the study it is possible, to characterize the protein such as determining the protein sequence. When the $\mathrm{N}$ - and $\mathrm{C}$ - termini of 
sequence can be determined, we will design DNA primers to obtain the encoding gene by using the Polymerase Chain Reaction (PCR) technique in combination with Reverse Transcriptase reaction (RT-PCR) from the plant. After obtaining the gene, we can determine whole DNA sequence of the gene in which amino acid sequence should be deduced. In order to further characterize the function and structure of the protein, mili-gram order of sample is needed, in which typical bacterial gene expressions may cause an inclusion body because the protein target should have antibacterial activity. In such case, we will try to use in vitro expression system.

\section{Acknowledgements}

I would like to express my deepest sense of gratitude and respect to my most honorable teacher and Thesis supervisor Dr. Niranjan Kumar Sana, professor, Department of Biochemistry and Molecular Biology, University of Rajshahi for his constant supervision, scholastic guidance, invaluable suggestions, immense encouragement, cordial affection and untiring patience during the whole period of research work and in preparing this dissertation. I am also expressing my grateful to all the Professor, Associate professor, Assistant professor, lecturer, officer and employee of Biochemistry \& Molecular Biology department.

\section{Reference}

[1] Alam, Z. (1936). Cytologocal studies some Indian Oleiferous Cruciferae3. Ann. Bot1, 85-100

[2] Wagstaff, D,J Genesis to Genesis: A historic perspective of plant toxicology. In: Toxic Plants and Other Natural Toxicant(eds. Tam G. and Catherine A.B), 1998, p.9-10

[3] Lis \& Sharon,N (1977), In “The antigens” (M. Sela.cd.). Vol.4, pp.429-529. Academic Press, New york.

[4] Laemmli UK (August 1970). "Cleavage of structural proteins during the assembly of the head of bacteriophage T4". Nature 227 (5259): 680-685.

[5] Smith, Jr. and G. M. Hieftje, Applied Spectroscopy; 1983, 37, 419-424.

[6] Lowry, O.H., N.J. Rosenbrough, A.L Farr and RJ. Rendall (1951). Protein measurement with the Folin Phenol reagent, Biol, Chem. 183: $265-275$.

[7] Meyer B.N., Ferrigni N.R., Putnam J.E., Jacobssen L.B., Nichols D.E., Mclaughlin J.L. brine shrimp, A convenient general bioassay for Active Plant Constituents, Plant Med., 45(1): 31-34, 1982.

[8] Finney, D.J., Probit Analysis : A statistical treatmentof sigmoid response curve. Cambridge University Press, London, $333,1947$. 